回 $25 \mathrm{r}$ ずつの照射を 4 回行なった場合と, 全照射量 $50 \mathrm{r}$ を分画して毎週 1 回ずつの照射を 2 回行なった場合とに ついて実験を行なった。

湘定項目は，体重, 赤血球数, 自血球数, 血色素量, 及び頜食能で，貪食能は我々がすでに発表した carbon black P-33 を用いる法で行い，頜食率で現わした。

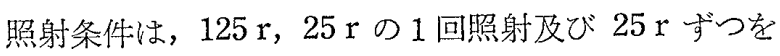
分劃して照射した場合は， ${ }^{60} \mathrm{Co}$ 線源を用い，線源亡家 鬼との距離は $1 \mathrm{~m}$ で，腹背方向で照射した。照射線量 率は $125 \mathrm{r}$ 照射の場合は $5.5 \mathrm{r} / \mathrm{min}$ で，25r 照射の 場合は $1.8 \mathrm{r} / \mathrm{min}$ であった。また $100 \mathrm{r}, 75 \mathrm{r}, 50 \mathrm{r} の$ 1 回照射の場合は，管電王 $/ 60 \mathrm{kv}, 2$ 次電流 $6 \mathrm{~mA}$ で, 附加フィルターは $0.40 / \mathrm{mm} \mathrm{Cu}+1.0 \mathrm{~mm} \mathrm{Al}$ を用い， 焦点・家鬼問の距離は $1.2 \mathrm{~m}$ で，同じく腹背方向で照

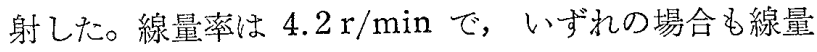
率の測定は Victoreen $\mathrm{r}$ meter 使用した。

体重, 血色素量及び血球数の変化では，125 r 1 回照射 群で著明な体重減少と白血球数の減少とがみとめられ， 100r 1 回照射群でわずかの白血球数の減少が認めら礼， 他の照射群ではなんらの変化も認められなかった。しか るに貪食率に招いては，25 r 1 回照射群之 $50 \mathrm{r}$ を 2 回に 分㓶して照射した群とを除き，他のすべての群に著明な 減少を認めた。従って放射線照射の影響が白血球数等に 変化の現われる以前に，食食率に変化の現われることを 見出した。また分画照射した場合は，同じ線量を 1 回照 射した場合に比し，その影響が徐々に現われしかもそ の度合が低いことが認められた。

\section{6. 原子炉事故時の救急処置に関する基礎的研究}

勝沼晴雄, 吉沢康雄, ○金安淑子

（東大医放射線健康管理）

目的:

原子炉事故時に放出される核分裂生成物は体内活染の 危鄎性を有しているが，とくに放射性ヨードは，

1. 原子炉設置基準の設定，事故時の災害評洒侮し て，最も重要な核種であること，

2. 放出核種のウで人体に攵入，與下され，Critical Organ である甲状腺に椇取され，障害を発生する危険 性があること，

の 2 点より重要視されており，施設，人体雨側面からの 対策が望まれている。著者らは，原子炉事故時の従業員 の救急処置の钼点加ら，放射性ヨードの体内行動と甲状 腺掑取阻止注つ基礎実験を行なった。
方法：

動物; Wister 系 Rats 우 $100 \sim 150 \mathrm{~g}$

放射性ヨード; ${ }^{131} \mathrm{I}$ 約 $10 \mu \mathrm{c} / \mathrm{kg}$

甲状腺摄取阻止剤; 韭放射性ヨード

抗甲状腺剂 (Methylthiouracil)

チォシアン酸カリ

投与方法；経口投与（霄ゾンデ使用）

放射能測定； NaI(T1) Scintillation Counter 結果㘧よび考察：

1. ${ }^{131} \mathrm{I}$ は腸管から大部分吸収され，甲状腺以外の臓 器は 3 時閒後に最大に達し，24時間後には1\%以下とな る。甲状腺は24時間後には飽和状態 $(22.5 \%)$ に達し。 他は大部分尿中より排泄される。

2. KI，Methylthiouracil は投与量，投与時間適 切に選ぶことにより，旧状腺摂取率，乙たがって被懪線 量を減少させることができる。とくにMethylthiouracil は ${ }^{131}$ I 撖取後長時間経過してから投与しても充分な效 果があり，両者に作用機序の差異が認められる。

3. KSCN では大きな効果は認められず，とくに投 与時間によっては， ${ }^{131}$ I の摂取促進の傾向も存在する。

これらの結果につき，既存の人体のデータと比較し， 副作用を考虑しながら，人体への適応につき検討した。

\section{騒 音・振 動}

\section{7. オクターブバンド騒音による聴覚の一時的閾值} 移動について

庄司 光, 山本岡夫, ○高木興一 (京大工衛生工学)

㯖筧の一時的閾值移動 (TTS) から騒音の恕限度を決 定しよらとする場合に，まず問題になるのは，騷音の種 類, 強さ, 曝露時間により生じる TTSが, ぞのように 変化するかといらことである。そこで， 3 名の被検者を 用以，2500 $500 \mathrm{cps}, 500 \sim 1000 \mathrm{cps}, 1000 \sim 2000 \mathrm{cps}$, $2000 \sim 4000 \mathrm{cps}$ の 4 種のオクターブバンド騒音につき， OBL $80 \mathrm{db}$ から $105 \mathrm{db}$ まで $5 \mathrm{db}$ ステップで, 5 分 〜155 分間曝露を行い, $1 \mathrm{kc}, 2 \mathrm{kc}, 3 \mathrm{kc}$, および $4 \mathrm{kc}$ の TTSを測定した。

艺の絬果, $2000 \sim 4000 \mathrm{cps}$ の場合は $3 \mathrm{kc}$ と $4 \mathrm{kc}$ で大きな TTS を生じ，I kc では曝露時間が長くなっ. てもほとんどTTSを生じなかった。 1000〜2000 cps では挑と $2 \mathrm{kc} 3 \mathrm{kc}$ KTS を生じ，瀑露時間 